\title{
COMMUNITY SERVICE THROUGH FACILITATION OF PARAGLIDING TOURISM CHSE GUIDELINES TRAINING
}

\author{
Ismayanti ISMAYANTI \\ Sahid University, Indonesia \\ ismayanti_istanto@usahid.ac.id
}

\begin{abstract}
Paragliding tourism is a breathtaking form of air adventure that impacted from Covid-19 pandemic as the activities is highly in human touch particularly tandem flight. There is a significant need for applying CHSE in each element of paragliding tourism. Thus, it is the purpose of this community service to facilitate and socialize the CHSE for paragliding tourism in flying site at Puncak Bogor West Java. 50 participants for stakeholder of paragliding tourism were participated in-class training for 4 hours and continued with out-class simulation out-door for 6 hours and wrapped up with paragliding flight for 1 hour. The result of training was monitored using checklist (see table below) of paragliding tourism CHSE. The list consists of criteria, indicators, and proven evidence. General conduct due to Covid-19 pandemic was socialized while the flow of service in nine area of paragliding flying sites were exercised in the field. It is expected that implementation of paragliding tourism CHSE manual could minimize the risks of transmission and each step-in service flow is constructed to avoid the impact of the pandemic. By practicing the manual, it is an encouragement for the stakeholder in paragliding tourism to rejuvenate and prepare to be visited with new tourist who more conscious with safety and health issues during their holiday.
\end{abstract}

Keywords: CHSE, Paragliding Tourism, Application

\section{BACKGROUND}

Indonesia is facing an unprecedent global health, social and economic emergency due to the Covid-19 pandemic, tourism sector is one amongst those most effected with travel restriction, hotels closed and flight reduction (UNCTAD, 2021)(United Nations, 2020). People want to know and receive information and knowledge about every aspect of destination to be visited. Now nobody is going anywhere yet but there will be more and more tourists who want to travel. As soon as the authorities open their destinations, people will actively plan their trips. Safety and health issues will be put into consideration; thus, destination management organization should prepare standard operational procedures (SOP) regarding health protocols for management, employee, and tourist. Ministry Tourism and Creative Economic (MOTCE) of Indonesia has made Cleanliness, Healthiness, Safety and Environment Friendly (CHSE) manual for every aspect of tourism including Paragliding Tourism.

Paragliding is a recreational aerospace sport as well as one of adventure tourism. This sport of free flying using parachutes takes off on food for recreational purposes (Indardi et al., 2019). Paragliding is one of the youngest aero sports and is one of specific ways of recreation which include free flying through air using specific means of transportation, paraglider, which is moving using wind. The most important precondition for safe flying are personal attitude, complete training and safe equipment (Pavic et al., 2013). The activities can be developed well when it is supported by natural resources, human capital, infrastructure, and services. Paragliding tourism is highly human interaction, and it will relate to CHSE when the paragliding adventure involves strapping the pilot onto the passenger in tandem paragliding flight. Paragliding tourism consist of dimensions such as: challenge-skill balance, sense of control, time distortion, clear goals and focus attentions (Ayazlar, 2015).
Implementing the manual, it is a need of training for those who are unknown to this matter. All stakeholder in paragliding tourism need to implement the guidelines for assurance. Thus, as community service, it is the purpose of this paper to facilitate the training and practice of paragliding tourism CHSE manual in the paragliding flying site at Puncak Area, Bogor, West Java.

\section{METHODS}

The manual of CHSE in Paragliding Tourism is derived from Indonesian Ministry of Health Policy about Health Protocol for Community in Public Space due to Covid-19 prevention and monitoring. The SOP focuses on adjustment of all activities of paragliding tourism toward general health protocol for Covid-19 prevention. Aim of the manual is: to increase awareness toward CHSE caused by Covid-19 pandemic. The manual is needed due to demand changes of tourist behavior who seeks CHSE based tourism activities. Tourism industry particularly paragliding operators must be prepared applying CHSE manual $\mathrm{n}$ their products and services. Not only operators, staff in flying sites, tourists, government, and all stakeholders must apply the manual. In this community service, implementation the manual was conducted using methods of training both in-class and off-class with 50 participants consists of paragliding operators, pilots, and staffs in airfield at Puncak Area, Bogor, West Jawa. In-class training was done for 4 hours and continued with out-class simulation out-door for 6 hours and wrapped up with paragliding flight for 1 hour. The result of training was monitored using checklist (see table below) of paragliding tourism CHSE. The list consists of criteria, indicators, and proven evidence. 
Table 1. Checklist Of Application Paragliding Tourism CHSE Manual

\begin{tabular}{|c|c|c|c|}
\hline No & Criteria & Indicator & $\begin{array}{c}\text { Supporting } \\
\text { Evidence }\end{array}$ \\
\hline \multicolumn{4}{|c|}{ SPECIAL GUIDE } \\
\hline \multirow{11}{*}{\multicolumn{2}{|c|}{ 1. Arrival Area }} & A. Manager & \\
\hline & & $\begin{array}{l}\text { A.1. Provides rules for } \\
\text { managing traffic } \\
\text { and crowd flow in } \\
\text { the parking area }\end{array}$ & $\begin{array}{l}\text { Document of } \\
\text { traffic flow } \\
\text { management } \\
\text { rules }\end{array}$ \\
\hline & & $\begin{array}{l}\text { A.2. Set the queue } \\
\text { to enter the gate } \\
\text { with a distance of } \\
\text { at least } 1 \text { meter, } \\
\text { be given a special } \\
\text { sign that is easy } \\
\text { to see, or make } \\
\text { arrangements for } \\
\text { tourist entry flow. }\end{array}$ & $\begin{array}{l}\text { Queue settings } \\
\text { instructions }\end{array}$ \\
\hline & & $\begin{array}{l}\text { A.3. Provide an area } \\
\text { to clean the } \\
\text { flying equipment } \\
\text { of tourists and } \\
\text { officers in } \\
\text { accordance with } \\
\text { safe procedures. }\end{array}$ & Photo area \\
\hline & & $\begin{array}{l}\text { A.4. Set up and limit } \\
\text { queues to the } \\
\text { registration area. }\end{array}$ & $\begin{array}{l}\text { Queue settings } \\
\text { instructions }\end{array}$ \\
\hline & & $\begin{array}{l}\text { A.5. Install a map of } \\
\text { the location of } \\
\text { evacuation lines } \\
\text { and gathering } \\
\text { points }\end{array}$ & $\begin{array}{l}\text { 1. Map of eva- } \\
\text { cuation path } \\
\text { locations } \\
\text { 2. Evacuation } \\
\text { signs }\end{array}$ \\
\hline & & $\begin{array}{l}\text { A.6. Appoint and } \\
\text { deploy officers } \\
\text { to oversee the } \\
\text { implementation of } \\
\text { health protocols }\end{array}$ & $\begin{array}{l}\text { Supervisory } \\
\text { Task Force } \\
\text { Assignment } \\
\text { Letter }\end{array}$ \\
\hline & & B. Tourists and Officers & \\
\hline & & $\begin{array}{l}\text { B.1. Park the vehicle } \\
\text { in accordance } \\
\text { with existing } \\
\text { instructions and } \\
\text { rules }\end{array}$ & $\begin{array}{l}\text { 1. Photo of the } \\
\text { parking area } \\
\text { 2. Driving parking } \\
\text { procedures } \\
\text { in pictures or } \\
\text { information } \\
\text { boards }\end{array}$ \\
\hline & & $\begin{array}{l}\text { B.2. Keep a distance } \\
\text { from others at } \\
\text { the entrance }\end{array}$ & $\begin{array}{l}\text { 1. Guidelines for } \\
\text { the implemen- } \\
\text { tation of } \\
\text { paragliding } \\
\text { flight health } \\
\text { protocols } \\
\text { 2. Pictures/ } \\
\text { photos keep } \\
\text { your distance }\end{array}$ \\
\hline & & $\begin{array}{l}\text { B.3. Wash your } \\
\text { hands with soap } \\
\text { and running } \\
\text { water or use } a \\
\text { hand sanitizer } \\
\text { while in the } \\
\text { arrivals area. }\end{array}$ & $\begin{array}{l}\text { 1. Guidelines } \\
\text { for the imple- } \\
\text { mentation of } \\
\text { paragliding } \\
\text { flight health } \\
\text { protocols } \\
\text { 2. Photos of } \\
\text { washing your } \\
\text { hands }\end{array}$ \\
\hline
\end{tabular}

\section{RESULTS AND DISCUSSION}

During in-class training, two section of material was explained. Those were (1) general guidance for operators, for staffs including tandem pilots and for tourist, and (2) flow of paragliding tourism activities with application of CHSE.

In core section, all stakeholders must conduct general items in Covid-19 prevention and monitoring that are: regularly wash hands with soaps in running water or using hand-sanitizer, always use mask and/or face-shield while in the paragliding flying sites, maintain physical distancing for at least one meter, avoid physical contacts, and lways in good health condition when entering paragliding flying sites. By means that everyone should not in fever, cough, flu, laryngitis and/or shortness of breath.

For operators, besides above general items, they should (1) pay attention to current information regarding Covid-19 prevention and monitoring, (2) make sure all staffs in good health condition, (3) regularly communicate paragliding tourism CHSE manual to staffs, tourists and other stakeholder in paragliding flying site, (4) train the staff to conduct manuals, (5) provide all written information about general items that can be read by everyone in flying site, (6) provide tools and equipment for CHSE such as thermometer, first aid medicines, water basin, handsanitizer, waste bin, etc., (7) conduct body check temperature for everyone in flying site, (8) form task force to monitor implementation paragliding tourism CHSE manual, (9) reengineer technical layout in flying sites to manage visitor flow in queueing, (10) make sure everyone use their own mask, and finally (11) make sure paragliding tourism flight conduction in wind speed of $0-25 \mathrm{~km}$ per hour.

For staffs, they should (1) pay attention to current information regarding Covid-19 prevention and monitoring, (2) make sure to work in good health condition, (3) do general cleaning at least three times a day with disinfectant, (4) do cleaning for every equipment used before and after flying, (5) remind tourist to follow health protocols, (6) do proper ethic when cough a sneeze.

For tourists, they should (1) pay attention to current information regarding Covid-19 prevention and monitoring, (2) make sure to visit the site in good health condition, (3) park vehicle in provide area, (4) maintain physical distancing and (5) use masks and/or face shield.

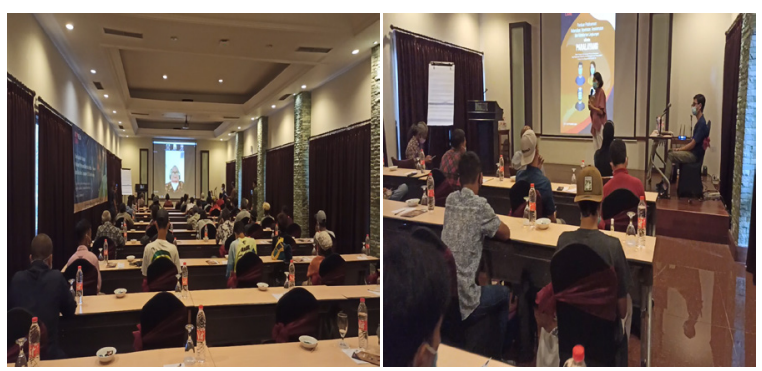

Figure 1. In-class training

In out-class session, the flow of service was applied in nine area of paragliding flying sites which are:

1. departure area,

2. registration area for solo pilot and for tandem paragliding, 
3. viewing area for spectators,

4. waiting bay for flying solo and tandem passenger,

5. fitting area where equipment had on solo pilot and tandem passenger,

6. take-off area to start flying,

7. flying area,

8. landing area to end flying and equipment disband, and

9. pick-up area.

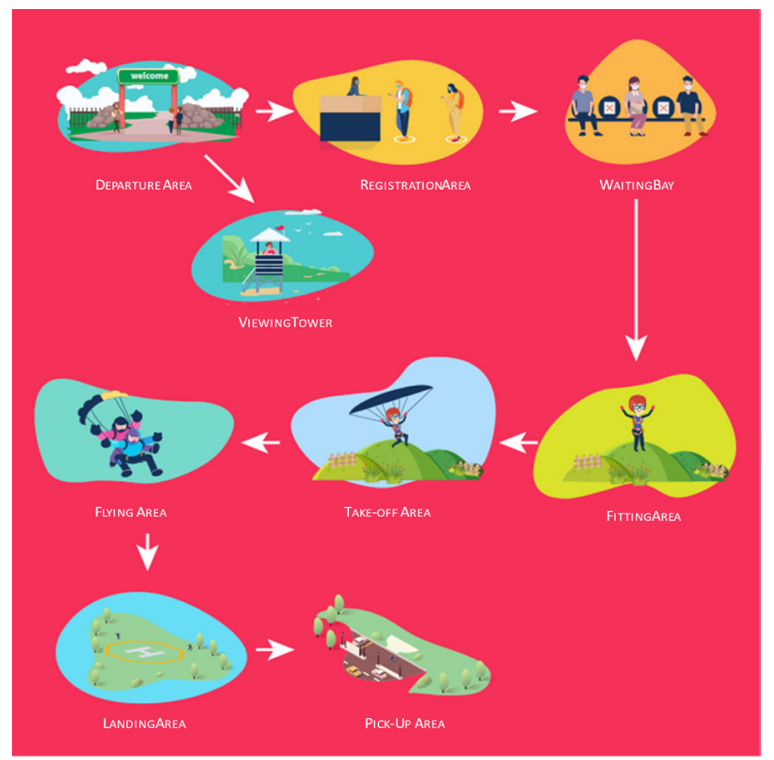

Figure 2. Service Flow of Paragliding Tourism

Source: (Kemenparekraf, 2020)

As paragliding is a complex product made up of several coordinated services, there is a need on practicing paragliding with application of CHSE in every area, start from departure area and finish in pick-up area. In departure area, operator must re-manage the traffic and the crowd in parking area as well as re-arrange the queue at entrance gate involving maintain physical distancing of one meter at least. Body temperature is checked. Flying equipment brought by solo pilots and those that will be used by tandem passengers are disinfected. Special mark and partition could be placed to separate direct interaction. Management provides evacuation map and shows meeting point at entrance gate so visitor can understand and know what to do during emergency. At registration area, reception table is equipped with hand sanitizer and partition is placed as separator between front desk officer and tourist who do registration. The use of online registration, that collect travel history and health condition of tourist, as well as electronic payment including non-cash refund system are highly recommended to reduce human touch. Registration officer conducts effective communication whenever explaining the rules and regulation of paragliding CHSE activities before flying.

After register and settle the payment, tourist or paraglider will be on hold in waiting bay. Operator must ensure the cleanliness of area by regularly disinfect or clean the furniture and area at least three times a day. During waiting, mask is on, and everyone regularly washes hand with soap or uses hand-sanitizer. While tourist or paraglider waiting, fitting officer prepares the equipment for paragliding will be used, it should be cleaned and accordingly disinfected. Each set gear is placed in distance with other gear. Once equipment ready, the tourist or paraglider will be called to enter the fitting area and outfitted with paragliding equipment. Fitting officer helps the gear fitting in accordance with health and safety protocols for both solo flight and tandem. Once it is done, fitting officer recheck the paragliding gears and escort the paraglider into take-off area. Parachute roll up by fitting officer in accordance to paragliding standard. Make sure the paraglider or tourist is hand-sanitized before take-off.

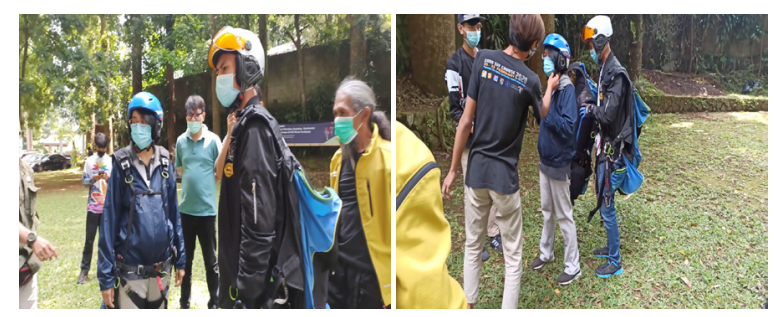

Figure 3. Out-class Simulation

During flight, operator must ensure clear air space and in accordance with the regulation. In tandem flight, pilot must be aware with paragliding safety and health protocol, talks to passenger as necessary, not doing extreme maneuver and ensure passenger masks on. Moreover, passenger enjoys the flight, not allowed to scream, and spit.

In landing area, operator set clear and clean area. Landing officer unleashes equipment from passenger, tandem pilot, and solo paraglider once touchdown. Officer also cleans and disinfects the gear thus equipment is ready to be used for next tandem and solo flight. All passenger, tandem pilot and solo paraglider wash hand after landing and maintain distance with each other. In pick-up area, pick-up time and queueing flow are arranged by operator to avoid traffic and crowd. If pick-up service using public transportation, then inside vehicle should be cleaned and disinfected regularly. Capacity of vehicle is adjusted to health protocol.

In viewing area, operator arranges marked stand area with social distancing particularly when there is a queueing of spectators. Officer controls the visitor traffic, ensure no crowd in viewing bay. Keep the area clean and regularly disinfected to prevent virus transmission. Spectators always put mask on, maintain distance with other spectators and regularly wash hand or use handsanitizer.

In case of emergency (natural disaster and disorder), everyone including operator, office, and tourist heads to existing meeting point to do next evacuation. If there is an accident or an indication of Covid-19 symptom, operator provides first aid room stocked with medicine and provide access to call ambulance or vehicle equipped with first aid. Officer brings casualties or patient to first aid room, 
do emergency rescue, prepare ambulances to transport patient to the nearest hospital. Tourist report any incident and willing to be rescued if he or she is casualty or patient.

All those steps were explained and exemplified (see picture below). Participant were able to raise question and discuss further to reach an understanding. Outdoor simulation put participants into role play. Simulation was taken twice until no more question raise. As there were nine steps, there were three acts either as operator, as officer and as tourist in each step so every participant got involved in simulation.
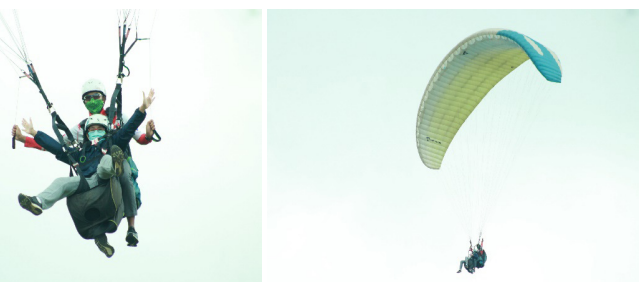

Figure 4. Real practice paragliding tourism CHSE manual

After simulation, the real practice was piloted. The trainer was acted as tourist and follow all paragliding tourism CHSE manual. Four trial flights were conducted and reviewed afterward. Check lists were used to monitor the result and it was found that most of the participant understood the step and able to conduct paragliding tourism CHSE manual, all indicators were fulfilled.

\section{CONCLUSION}

The sustainability of paragliding tourism during the Covid-19 pandemic is highly dependent on mitigations carried out so that actors do not get infected. Therefore, it is necessary to plan prevention the transmission through adaptation of changes in the new normal lifestyle even though paragliding tourism takes place outdoor but still human interaction is highly intense in these activities. By implementing this paragliding tourism CHSE manual is expected to minimize the risks of transmission. There are nine steps to be followed carefully and each step is constructed to avoid the impact of the pandemic. By practicing the manual, it is an encouragement for the stakeholder in paragliding tourism to rejuvenate and prepare to be visited with new tourist who more conscious with safety and health issues during their holiday.

\section{ACKNOWLEDGMENT}

This community development was achieved by collaboration with Directorate of Nature and Culture Tourism Product Development, Ministry of Tourism and Creative Economic where the author got opportunities to join the team in formulating the paragliding tourism CHSE manual and get responsibility to socialize the step to the stakeholder. Also thanking the paragliding flying site at Puncak Area, Bogor, West Java for practicing area of this manual.

\section{REFERENCES}

Ayazlar, R. A. (2015). Flow Phenomenon as a Tourist Experience in Paragliding: A Qualitative Research. Procedia Economics and Finance, 26(2013), 792-799. https://doi.org/10.1016/s22125671(15)00845-X

Indardi, N., Sahri, S., Sugiharto, \& Anam, K. (2019). Paragliding Triangle as Air Tourism Icon in Central Java. 362(Acpes), 90-93. https://doi.org/10.2991/ acpes-19.2019.20

Kemenparekraf.(2020). Panduan Pelaksanaan Kebersihan, Kesehatan, Keselamatan, dan Kelestarian Lingkungan. Https://Chse.Kemenparekraf.Go.Id/, 2019(September). https://chse.kemenparekraf.go.id/

Pavic, L., Rancic, M., \& Mijatov, M. (2013). Potential for paragliding tourism development in Niska Banja (South Serbia). Turizam, 17(3), 110-120. https://doi. org/10.5937/turizam1303110p

UNCTAD. (2021). Covid-19 and Tourism an Update. In Covid-19 and Tourism an Update (Issue June). https://unctad.org/system/files/official-document/ ditcinf2021d3_en_0.pdf

United Nations. (2020). COVID-19 and Transforming Tourism. Un.Org, August, 1-27. https://www. un.org/es/events/tourismday/ 